\title{
Ethnologies
}

\section{Kule Centre for Ukrainian and Canadian Folklore}

\section{Andriy Nahachewsky}

Volume 29, numéro 1-2, 2007

Retour à l'ethnographie

Back to Ethnography

URI : https://id.erudit.org/iderudit/018757ar

DOI : https://doi.org/10.7202/018757ar

Aller au sommaire du numéro

Éditeur(s)

Association Canadienne d'Ethnologie et de Folklore

ISSN

1481-5974 (imprimé)

1708-0401 (numérique)

Découvrir la revue

Citer cet article

Nahachewsky, A. (2007). Kule Centre for Ukrainian and Canadian Folklore.

Ethnologies, 29(1-2), 331-336. https://doi.org/10.7202/018757ar d'utilisation que vous pouvez consulter en ligne.

https://apropos.erudit.org/fr/usagers/politique-dutilisation/ 


\title{
Kule Centre for Ukrainian and Canadian FOLKLORE
}

\author{
Andriy Nahachewsky \\ University of Alberta, Edmonton \\ andriy.nahachewsky@ualberta.ca
}

The "Peter and Doris Kule Centre for Ukrainian and Canadian Folklore" is a research centre affiliated with the Ukrainian Folklore programs at the University of Alberta in Edmonton. Course offerings lead to BA, MA and PhD degrees in Ukrainian Folklore. The Kule Folklore Centre is the most important centre for Ukrainian folklore and ethnology outside of Ukraine, and the largest folklore research group in western Canada. The mandate of the Kule Folklore Centre is expanding beyond Ukrainian studies to include Canadian folklore more generally. The Faculty of Arts and the Department of Modern Languages and Cultural Studies, in which the Kule Folklore Centre is based, are open to the growth of additional folklore studies.

The Ukrainian Folklore program started with one introductory course in 1977 by Dr. Bohdan Medwidsky. It has now developed into a series of fifteen dedicated undergraduate and graduate courses, each offered either annually or biannually. Undergraduate courses include one course in general folklore, introductions to Ukrainian culture and to Ukrainian Canadian culture prior to 1930. Core courses for undergraduate and graduate students together include studies of Ukrainian folk song, prose, beliefs, rites of passage, calendar culture, material culture and folk arts, as well as dance. Graduate seminars are offered on the history of Ukrainian folkloristics, Ukrainian Canadian folklore, theory and methods.

A series of undergraduate and graduate awards recognize top students in various categories each year. Graduate students are particularly well supported with Ivan Franko research and teaching assistantships, an 
essay award, and travel bursaries. The Kule Postdoctoral Fellowship program has recently been established, allowing for a recent $\mathrm{PhD}$ graduate to work in the Kule Folklore Centre for up to three years.

Dr. Bohdan Medwidsky founded the Ukrainian Folklore programs, and served as core faculty member until his retirement in 2002. His research specializations included Ukrainian Canadian oral traditions (particularly proverbs), and the history of Ukrainian folklore studies. He was very active in development activities, raising funds to establish the Huculak Chair of Ukrainian Culture and Ethnography, which was occupied in 1990 by Dr. Andriy Nahachewsky. This was the first endowed professorial Chair in the Faculty of Arts, and led to significant expansion of the Ukrainian Folklore programs.

Dr. Nahachewsky completed his PhD at the University of Alberta under Dr. Medwidsky in the Department of Slavic and East European Studies. His dissertation, supported by a prestigious Isaac Walton Killam scholarship, tracked changes in Ukrainian Canadian participatory and theatrical dance forms over the twentieth century. His MA was also granted at the University of Alberta (1985), and he studied previously at the Oleksandr Korniichuk Institute of Culture (Kyiv, Ukrainian SSR, 1981), York University (BFA in Dance, 1982) and the University of Saskatchewan (BA in Ukrainian Studies, 1979).

Over his career, Dr. Nahachewsky has completed field research in folklore, dance and Ukrainian culture in Ukraine, Bosnia, Slovakia, Poland, Yugoslavia, France, Italy, Romania, the United States and across Canada. He has written numerous articles, chapters, reviews, proceedings, and research reports on Ukrainian and Canadian folklore, and particularly dance, for Ethnographica (Athens); Studia Musicologica (Budapest); Rodovid (Kyiv); Dance Research Journal, Journal of American Folklore and other publications. Research interests include vernacular dwelling architecture, folk arts and crafts, western Canadian local culture, ethnic identity, and ethnographic methodology. He has been editor for numerous books and multimedia projects.

Nahachewsky has made nearly one hundred presentations at conferences, symposia and workshops on ethnology, folklore and dance in China, Romania, England, Italy, Croatia, Slovakia, Ukraine, as well as across Canada and the United States.

His interest in folklore was inspired by a strong and continuing engagement with Ukrainian dance, as a performer, choreographer, instructor and critic. He has served as an expert assessor for the Canada 
Council, Dance Section, and has adjudicated a multitude of Ukrainian dance competitions. His reputation as an ethnochoreologist has lead to participation in diverse research projects on culturally specific dance.

Nahachewsky's roles as Huculak Chair and as Director of the Kule Folklore Centre involve substantial administrative duties. He is Curator of the Bohdan Medwidsky Ukrainian Folklore Archives, and a member of the University of Alberta Museums Policy and Planning Committee. $\mathrm{He}$ is an active member of many community organizations and committees with interests in Ukrainian culture, folklore, dance and museumology. He has served as co-organizer of numerous conferences, including several annual meetings of FSAC.

In 2004, the faculty of the Ukrainian Folklore programs was increased with the arrival of Dr. Natalie Kononenko, former professor of Slavic Languages, Literatures and Folklore at the University of Virginia. She was appointed as the first occupant of the newly founded Kule Chair in Ukrainian Ethnography. Like the Huculak Chair before it, the Kule Chair was permanently endowed following a major gift by members of the Ukrainian community in Canada.

Dr. Kononenko holds a PhD from Harvard University, granted jointly by the Departments of Slavic Languages and Literatures and Near Eastern Languages and Literatures. She did her fieldwork in Turkey and wrote about the Turkish minstrel tale tradition. Her master's degree is also from Harvard University, and her bachelor's degree is from Radcliffe College. She also attended Cornell University.

Kononenko's publications include Ukrainian Minstrels: And the Blind Shall Sing which received the Kovaliv prize in 1997 and the American Association for Ukrainian Studies best book award in 2000. Other books are The Magic Egg and other Tales from Ukraine (Libraries Unlimited), The Turkish Minstrel Tale Tradition (Garland), and Ukrainian Dumy (CIUS/HURI). Her Slavic Folklore Handbook is due to be published in 2007.

Kononenko's articles, covering topics such as weddings, laments, beliefs about the afterlife, witchcraft stories, material culture, and folk medicine have appeared in every major North American publication, including Ethnologies and Slavic Review. She has also contributed book chapters to volumes dealing with folk religion, women's issues, and Robin Hood stories around the world. Kononenko wrote the entry on Ukraine for the Greenwood Encyclopedia of World Folklore. 
An accomplished speaker, Kononenko has been invited to lecture in Ukraine, Poland, France, Turkey and other international venues. She has also delivered invited lectures across Canada and the United States, including the Ivan Franko lecture in Ottawa.

Digital media are very important in Kononenko's work. Her website, "Ukrainian Traditional Folklore" (www.arts.ualberta.ca/uvp), is used at the University of Alberta and many other institutions. The website is constantly updated with new materials from Ukraine. Since coming to Alberta, Kononenko has also started to document Ukrainian folklore in Canada, including pysanky (Ukrainian Easter eggs), churches, and traditional baking. The latest project is a unit for the Ukrainian bilingual program aimed at grades 3 and 4 . This unit was tested in the Edmonton public schools in 2006-2007.

In addition to her role as Kule Chair, Kononenko is also very active in the administration of the Department of Modern Languages and Cultural Studies, and serves on several University-wide committees, notably those dealing with computer resources. She is active in many professional organizations, and is currently Editor of Folklorica, the journal of the Slavic and East European Folklore Association.

The graduate programs in Ukrainian Folklore are very active. Twenty five young scholars have completed MA degrees on Ukrainian folklore themes at the University of Alberta since 1963, and seven have completed doctorates. Nine graduate students are registered in 2007. Twenty-three of the forty-one total thesis and dissertation projects deal specifically with Canadian Ukrainian folklore, thirteen deal with folkloric phenomena in Ukraine or other countries, and five are geographically comparative. Research themes are diverse, and include oral lore (12), performing arts (9), worldview and spiritual culture (9), as well as material culture (5), customs and rites (5), and the history of folklore studies (2). Several graduates have secured academic positions, while others have pursued further graduate schooling or careers in museums, archives, library work, research, community leadership, nursing, performing arts, theology, teaching, government, social service agencies, and elsewhere.

As noted above, the Ukrainian Folklore programs grew with substantial contributions from the Ukrainian communities in Canada, and certain individuals in particular. Wasyl and Anna Kuryliw founded the Ivan Franko Scholarships in 1987 to support graduate students. 
Erast and Lydia Huculak made a major donation to establish the Huculak Chair in 1989. Bohdan Medwidsky has been a constant donor, establishing the Ukrainian Folklore Archive, which now bears his name. Peter and Doris Kule contributed major gifts in 2004 to create the Kule Chair, and again in 2006, resulting in the Kule Postdoctoral Fellowship and the renaming of the greatly expanded Kule Centre for Ukrainian and Canadian Folklore. The Centre is also grateful to numerous other benefactors, as well as the Government of Alberta and the University of Alberta for their support.

The Kule Folklore Centre (originally called the Canadian Centre for Ukrainian Culture and Ethnography) was established in 2001 as an umbrella administrative unit to coordinate activities arising from the Ukrainian Folklore programs and the several growing endowments dedicated to this field. Dr. Nahachewsky has served as Director of the Centre since that time. Lynnien Pawluk serves as the Kule Centre Coordinator. The endowments ensure a permanent and stable base for Ukrainian and Canadian folklore studies at the University of Alberta.

The Ukrainian Folklore Archives (named after Dr. Medwidsky in 2003) were founded in 1977 as students' fieldwork projects began to be collected for posterity. The Archives contain student essays and other manuscripts, fieldwork notes, a reference library, as well as audio and video field recordings in numerous formats, photographs, slides, posters, commercial recordings, a large collection of printed ephemera, and a small teaching collection of artifacts. The materials focus on Ukrainian and Ukrainian Canadian traditions, with some materials from Ukrainian communities in other countries. Dance, music, calendar and life cycle celebrations are well represented, as well as performing arts traditions, which often have a strong folk connection in the Ukrainian tradition.

Archivist Nadya Foty manages numerous part-time research assistants to continuously accession new materials and to further work on catalogues of the archival collections. A searchable web interface for photographs, publications, commercial and field audio/video recordings is expanding. This website is supported by the Museums and Collections Service at the university, and is accessible through the Kule Folklore Centre's website at www.ukrfolk.ca. The Kule Folklore Centre actively cooperates with other Ukrainian Canadian archives and museums. 
The project "Local Culture and Diversity on the Prairies" was a shared initiative supported by federal and provincial governments and several research partners, documenting everyday life, ethnocultural identity and regional variation among people of Ukrainian, French, German and English heritage prior to 1939 on the prairies. Interviews with some 800 individuals were recorded across Alberta, Saskatchewan and Manitoba. Nahachewsky designed the project and served as principal investigator. A powerful search tool is being developed to deliver the audio materials directly over the internet for researchers and the general public.

Natalie Kononenko's fieldwork interviews from Ukraine are now available online (http://projects.tapor.ualberta.ca/UkraineAudio). The recordings contain folk narratives, songs, discussions of folk beliefs, rituals and much more. The sound files are searchable by subject category. Other projects of the Kule Folklore Centre include a Ukrainian wedding exhibit (web-based and as a wall installation), dedicated to the complex tradition of Ukrainian wedding ritual in Ukraine and Canada, historically and in recent years.

The Kule Folklore Centre and its various researchers have been involved in a number of book publications, including memoirs by Peter Svarich and Walter Sharek; Word and Wax: A Medical Folk Ritual Among Ukrainians in Alberta (R. Hanchuk); Migrations: From Western Ukraine to Western Canada; Plants in folk beliefs of Rusyns-Ukrainians of Priashiv (N. Varchol, in Ukrainian); Social Dances of Ukrainians of Canada (A. Nahachewsky, in Ukrainian); Albums (D.P. De la Fliz, in Ukrainian, 2 vols); Ukrainian Proverbs (W. Plaviuk, in Ukrainian, 2 vols); The Tsymbaly Maker and His Craft (M. Bandera).

Prospects for the future of the Ukrainian Folklore programs and the Kule Folklore Centre are good. Five strategic priorities of the Kule Centre have been identified to guide future growth. These include teaching undergraduate and graduate programs; conducting fieldwork and maintaining a growing archive; developing internet resources; reaching out to the community; and supporting researchers and students with scholarships and assistantships.

Andriy Nahachewsky, Lynnien Pawluk and Natalie Kononenko 